\title{
Structure Validity of the Religious Schema Scale in Greek
}

\author{
Miltiadis Proios \\ Dept. of Physical Education and Sport Science, \\ Aristotle University of Thessaloniki, Greece \\ TEFAA, Aristotle University of Thessaloniki, 57001, \\ Thermi Thessaloniki, Greece
}

Tel: 30-231-099-2472 E-mail: mproios@phed.auth.gr

Received: September 21, 2014 Accepted: October 24, 2014 Published: December 31, 2014

doi:10.5296/jsss.v2i1.6844

URL: http://dx.doi.org/10.5296/jsss.v2i1.6844

\begin{abstract}
The purpose of the present study was to examine structure validity of RSS using in a Greek sample. Participants were 266 individuals (men $n=109$, and women $n=157$ ). Their age ranged from 13 to 86 years old $(M=27.03, S D=16.29)$. Factor (confirmatory and exploratory) analyses were conducted. Several criteria were used to test the hypotheses factor structures of the RSS. The results of the present study did not support the 15-item 3-factor model, but presented a satisfactory solution regarding the use of the 13-item 3-factor model. Conclusively we could state that RSS is an instrument that presents satisfactory psychometric properties and could be used for Greek people.
\end{abstract}

Keywords: Religious Schema Scale, Structure validity, Greek sample 


\section{Introduction}

According to Streib's (2010) view, the definition of a "religious schema" rests on the key characteristic that a schema links an experience with an interpretation in such a way as to open up the possibility on transformation of the experience (p. 6). The religious schemata are the distinguishing marks for religious styles (Streib, Hood, \& Klein, 2010, p. 154). While religious styles are reported to be related to the life style and habits of people (Bourdieu, 1979), they appear to have a repeated use of specific interpretation patterns for coping with rituals or behavioral structures in religion (Streib, 2010).

The study of religious schemata is rather interesting since it presents us with a cognitive interpretation pattern which a person seeks and prefers in order to cope with everyday issues. Knowing the religious schema can indeed assist the scientific community and especially those dealing with the study of human behavior since it offers prior study on human behavior. McIntosh (1995) supported that_a schema is a cognitive structure or mental representation containing organized, prior knowledge about a particular domain. Also, through religious schemata possible differences in ways of thinking in individuals carrying various cultural characteristics and religious beliefs may be examined.

Streib, Hood, and Klein appreciated the importance of studying the religious schemata and developed Religious Schema Scale (RSS; Streib et al., 2010). RSS is a new instrument for measuring differences in religious styles and schemata. The development of this scale was based on Fowler's model of faith development (Fowler, 1981). Fowler suggested that the development of religious faith is achieved on six stages (intuitive-projective faith, mythic-literal faith, synthetic-conventional faith, individualized-reflective faith, conjunctive faith, and the rarely attainable and final universalizing faith stage) (Fowler, 1986). Nevertheless, the views of Fowler on stage theory have been heavily criticized (Streib et al., 2010).

Streib et al. (2010) considered the criticism and suggested the reformulation of Fowler's six stages into three basic schemas. These were the ones to design RSS for measuring religious schemata. These schemata are assessed through three subscales: truth of test and teaching $(\mathrm{ttt})$, fairness, tolerance and rational choice (ftr) and xenosophia, inter-religious dialox (xenos).

Structure validity of RSS was ensured through the use of factor analysis (exploratory and confirmatory). Check was done with the use of a sample carrying various cultural characteristics (Americans and Germans). Due to the fact that this scale was recently published there is no relevant bibliography on its validity. The use of RSS in other studies such as for example the present study with a sample carrying a variety of cultural characteristics and languages are expected to enhance even further its validity.

The purpose of the present study is to examine the structure validity of RSS within a Greek sample, while it is expected to find a three dimensional scale.

\section{Method}

\subsection{Participants}

The participants were 266 individuals (men $n=109$, and women $n=157$ ). Their age ranged 
from 13 to 86 years $(M=27.03, S D=16.29)$.

\subsection{Measurement}

The Religious Schema Scale (RSS; Streib et al., 2010) consisting of three subscales of 5 items each was used. Standardized back-translation procedures were used to develop a Greek version of the RSS using three independent bilingual translators (Brislin, 1986). The back-translation procedure was repeated iteratively until the original and back-translated English versions of the questionnaire were virtually identical. The RSS uses a 5-point Likert-type format from strongly agree to strongly disagree. Reliabilities of the three subscales in the current sample are: $\alpha=.88$ for subscale truth of texts $\&$ teachings (ttt), $\alpha$ $=.65$ for fairness, tolerance \& rational choice $(f t r)$ and $\alpha=.70$ for xenosophia \& inter-religious dialog (xenos).

\subsection{Procedure}

The sample used in this study lived in a city with a population of one million._The sample was randomly selected and individuals had similar cultural background and same religious faith (Christian Orthodox). The questionnaire was filled in the absence of researchers. Specifically, the participants were members of several organizations (religious and social) and the questionnaires reached them through other members of these organizations.

\subsection{Data Analysis}

For the sake of our study the initial thought was to use just CFA techniques to examine the structure of the RSS, as a better technique than the exploratory one (e.g., Blunch, 2008; Brown, 2006; Kline, 2005), but also because of priori knowledge of the number of factors, that is, on the structure linking observed variables to latent factors at the initial stages of the questionnaire development (Stevens, 1996). Nevertheless, considering the up to date findings which presented an unstable behavior on the issue of internal consistency, for example factor ftr presented scores of .76, .65, .65, 70, .88, and .86, while factor xenos .65, 70, .82, .66, 71, and .61 (Streib, 2011; Streib \& Klein, 2012; Streib, Hood, \& Klein, 2010, Streib \& Klein, 2014, and Watson, Chen, \& Morris, 2014, respectively), as well as on the claiming of researchers that CFA cannot be used for exploratory analysis (e.g., Asparouhov \& Muthen, 2009; Byrne, 2001; Gorsuch, 1983; MacCallum et al., 1992; Marsh et al., 2011). Both factorial analyses (exploratory and confirmatory) were used on the same sample. Also within the framework of examination of structural validity of RSS interrelations among the items and internal consistency reliability were examined.

\section{Results}

The aim of the present study was to validate the Religious Schema Scale (RSS) on a sample with different cultural backgrounds and language than the ones used in the original study.

\subsection{Interrelations Among the RSS Items}

If two tests are presumed to measure the same construct, a correlation between them is predicted (Cronbach \& Meehl, 1955). In the present study the interrelations among the items 
(questions) were estimated by factor analysis (Table 1). More specifically, highly significant correlations were found between items of the same construct as well as among other constructs. Most correlations between items of different constructs were lower. However, it should be noted that no significant correlation as well as of lower significance ones, were found between items of subscale fairness, tolerance $\&$ rational choice.

Table 1. Correlation matrix for the 15 items of the Religious Schema Scale

\begin{tabular}{|c|c|c|c|c|c|c|c|c|c|c|c|c|c|c|}
\hline & 1 & 2 & 3 & 4 & 5 & 6 & 7 & 8 & 9 & 10 & 11 & 12 & 13 & 14 \\
\hline 1.ttt1 & - & - & - & - & - & - & - & - & - & - & - & - & - & - \\
\hline 2.ttt2 & $.36^{\mathrm{a}}$ & - & - & - & - & - & - & - & - & - & - & - & - & - \\
\hline 3.ttt3 & $.58^{\mathrm{a}}$ & $.31^{\mathrm{a}}$ & - & - & - & - & - & - & - & - & - & - & - & - \\
\hline 4.ttt4 & $.67^{\mathrm{a}}$ & $.31^{\mathrm{a}}$ & $.61^{\mathrm{a}}$ & - & - & - & - & - & - & - & - & - & - & - \\
\hline $5 . \mathrm{ttt} 5$ & $.58^{\mathrm{a}}$ & $.33^{\mathrm{a}}$ & $.67^{\mathrm{a}}$ & $.68^{\mathrm{a}}$ & - & - & - & - & - & - & - & - & - & - \\
\hline 6.ftr1 & .06 & .11 & $.12^{\mathrm{b}}$ & .12 & .09 & - & - & - & - & - & - & - & - & - \\
\hline 7.ftr2 & $.19^{\mathrm{a}}$ & $.23^{\mathrm{a}}$ & $.19^{\mathrm{a}}$ & $.22^{\mathrm{a}}$ & $.19^{\mathrm{a}}$ & $.27^{\mathrm{a}}$ & - & - & - & - & - & - & - & - \\
\hline 8.ftr3 & $.28^{\mathrm{a}}$ & $.19^{\mathrm{b}}$ & $.21^{\mathrm{a}}$ & $.27^{\mathrm{a}}$ & $.24^{\mathrm{a}}$ & $.30^{\mathrm{a}}$ & $.34^{\mathrm{a}}$ & - & - & - & - & - & - & - \\
\hline 9.ftr4 & $.26^{\mathrm{a}}$ & .10 & $.19^{\mathrm{a}}$ & $.21^{\mathrm{a}}$ & $.21^{\mathrm{a}}$ & $.18^{\mathrm{a}}$ & .11 & $.48^{\mathrm{a}}$ & - & - & - & - & - & - \\
\hline 10.ftr5 & $.28^{\mathrm{a}}$ & $.16^{\mathrm{b}}$ & $.27^{\mathrm{a}}$ & $.25^{\mathrm{a}}$ & $.35^{\mathrm{a}}$ & $.18^{\mathrm{a}}$ & $.13^{b}$ & $.34^{\mathrm{a}}$ & $.34^{\mathrm{a}}$ & - & - & - & - & - \\
\hline 11.xe1 & $.19^{\mathrm{a}}$ & $.25^{\mathrm{a}}$ & $.23^{\mathrm{a}}$ & $.21^{\mathrm{a}}$ & $.19^{\mathrm{a}}$ & $.19^{\mathrm{a}}$ & $.31^{\mathrm{a}}$ & $.18^{\mathrm{a}}$ & .07 & $.38^{\mathrm{a}}$ & - & - & - & - \\
\hline 12.xe2 & -.11 & .03 & .01 & -.02 & -.08 & $.16^{\mathrm{a}}$ & $.26^{\mathrm{a}}$ & $.27^{\mathrm{a}}$ & .09 & $.22^{\mathrm{a}}$ & $.29^{\mathrm{a}}$ & - & - & - \\
\hline 13.xe3 & -.15 & .12 & -.11 & -.08 & $-.15^{b}$ & $.16^{\mathrm{b}}$ & $.22^{\mathrm{a}}$ & $.22^{\mathrm{a}}$ & .09 & $.21^{\mathrm{a}}$ & $.35^{\mathrm{a}}$ & $.34^{\mathrm{a}}$ & - & - \\
\hline 14.xe4 & $.16^{\mathrm{b}}$ & $.30^{\mathrm{a}}$ & $.24^{\mathrm{a}}$ & $.19^{\mathrm{a}}$ & $.29^{\mathrm{a}}$ & .03 & -.01 & .08 & .07 & $.31^{\mathrm{a}}$ & $.34^{\mathrm{a}}$ & $.27^{\mathrm{a}}$ & $.24^{\mathrm{a}}$ & - \\
\hline 15.xe5 & -.06 & $.13^{\mathrm{b}}$ & -.05 & -.08 & -.01 & -.02 & .10 & -.02 & -.12 & $.25^{\mathrm{a}}$ & $.34^{\mathrm{a}}$ & $.40^{\mathrm{a}}$ & $.36^{\mathrm{a}}$ & $.43^{\mathrm{a}}$ \\
\hline
\end{tabular}

\subsection{Factor Analysis}

Exploratory factor analysis (EFA). This analysis was used because the correlation between the observed and latent variables was uncertain (Byrne, 2001). RSS is a tool designed to measure three religious matters by the use of three different constructs. Thus, EFA was used to determine the extent to which the item measured (the observed variables) was related to the three latent constructs. Both the Bartlett test of thoroughness $\left(\mathrm{x}^{2}(105)=1281.50, p<\right.$ $0.001)$ and the Kaiser-Meyer-Olkin measure of sampling adequacy $(\mathrm{KMO}=0.801)$ indicated that factor analysis was appropriate for the data (Stevens, 1996). Items loaded with more than .40 were considered as loaded with one factor (Hinkin, 1995). Then, variants multi co-linearity was examined by means of communalities (Harman, 1976). Values that 
approached the unity were not considered a threat for the existence of multi co-linearity. The ratio in these cases was $266: 15$ or $17.7: 1$, covering the preconditions determined by some factor analysts (e.g., Gorsuch, 1983; Nunnally, 1978). Four factors derived from the analysis. At this point, it should be noted that an item (i.e., it is important to understand others through a sympathetic understanding of their culture and religion) of the factor $f t r$ was found to be loaded with two factors simultaneously and was therefore omitted as a problematic item (Agius et al., 2003). Then, factor analyses were recomputed on the 14-item scale. In this analysis a three-factor solution accounted for $55.79 \%$ of the total variance. The factor loadings and communalities are presented in Table 2.

Table 2. Pattern matrix for the RSS items (with oblique rotation solution), Communalities, and Cronbach's Alpha

\begin{tabular}{|c|c|c|c|c|}
\hline \multirow{2}{*}{ Variable } & \multicolumn{3}{|c|}{ Factors } & \multirow{2}{*}{$h^{2}$} \\
\hline & 1 & 2 & 3 & \\
\hline Truth of texts and teachings & \multicolumn{3}{|c|}{$\alpha=.84$} & \\
\hline $\mathrm{ttt} 1$ & .81 & & & .69 \\
\hline $\mathrm{ttt} 2$ & .51 & & & .36 \\
\hline $\mathrm{ttt} 3$ & .81 & & & .67 \\
\hline $\operatorname{ttt} 4$ & .82 & & & .71 \\
\hline $\mathrm{ttt} 5$ & .85 & & & .73 \\
\hline Fairness, tolerance, and rational choice & $\alpha=.61$ & & & \\
\hline $\mathrm{ftr} 1$ & & .61 & & .37 \\
\hline $\mathrm{ftr} 2$ & & .56 & & .39 \\
\hline $\mathrm{ftr} 3$ & & .78 & & .65 \\
\hline $\mathrm{ftr} 4$ & & .62 & & .44 \\
\hline Xenosophia/ inter-religious dialog & $\alpha=.72$ & & & \\
\hline xenos 1 & & & .63 & .50 \\
\hline xenos 2 & & & .61 & .51 \\
\hline xenos3 & & & .63 & .55 \\
\hline xenos 4 & & & .66 & .58 \\
\hline xenos 5 & & & .80 & .66 \\
\hline Percentage of variance explained & 27.15 & 17.41 & 11.24 & \\
\hline Eingenvalues & 55.79 & & & \\
\hline
\end{tabular}

Confirmatory factor analysis. A confirmatory factor analysis was applied because there was prior knowledge of the number of factors at the initial stages of the questionnaire 
development (Stevens 1996). A three-factor model was postulated (Table 3). The models were tested using confirmatory maximum likelihood (ML) factor analyses parameter estimates in AMOS 17.0. In addition, the variance-covariance matrices were analyzed using latent variable software programs AMOS 17.0. CFAs were applied because of prior knowledge of the number of factors, that is, on the structure linking observed variables to latent factors at the initial stages of the questionnaire development (Stevens, 1996). The ML algorithm was selected because it resulted in accurate fit indexes with ordered-categorical data that violate the assumption of multivariate normality (Hutchinson \& Olmos, 1998; Olsson, Foss, Troye, \& Howell, 2000). The ML algorithm is also a standard estimation technique with ordered-categorical data (Hoyle \& Panter, 1995). The multiple imputation method was used to address the issue of missing data in the present study (Schafer \& Graham, 2002). The sample size in the present study was adequate to estimate the various models based on two criteria: (a) the total sample size was larger than 100; and (b) the ratio of the total sample size to the number of freely estimated parameters should be greater than 10:1 and approximating 20:1 (Kline, 2005).

Four measures of model fit are reported: $x^{2}$, goodness-of-fit index (GFI), confirmatory fit index (CFI), and root mean square error of approximation (RMSEA). According to $\mathrm{Hu}$ and Bentler (1999), for GFI and CFI a cut-off value close to .90 and the RMSEA $\leq .05$ indicates close approximate fit; values between .05 and .08 suggest reasonable error of approximation, .08 and .10 marginal fit, and RMSEA > .10 suggests poor fit (Brown \& Cudeck, 1993).

On the first model the indicators of the original three-factor 15 -item was examined. The model showed no acceptable indicators of appropriateness $\left(\mathrm{x}^{2}(87)=309.3, p<.01\right.$, GFI $=.87$, $\mathrm{CFI}=.82$, and RMSEA $=.10)$. Then the appropriateness of the model produced by EFA in the three-factor 14-item was checked. This model did not consist a good model fit $\left(\mathrm{x}^{2}(74)=\right.$ $249.72, p<.001, \mathrm{GFI}=.89, \mathrm{CFI}=.84$ and RMSEA $=.10)$. Examination of the standardized residuals and the Langrange Multiplier test suggested that deleting one item (i.e., although every person deserves respect and fairness, arguments need to be voiced rationally) would result in significant improvements in model fit. CFA without this item resulted in a satisfactory model fit: $\mathrm{x}^{2}(62)=198.25, p<.001, \mathrm{GFI}=.91, \mathrm{CFI}=.87$ and $\mathrm{RMSEA}=.09$. All parameter estimates showed a marginally good model fit and are presented in Table 3. 
Table 3. Goodness-of-fit indices of models tested

\begin{tabular}{lllllll}
\hline Models & $\mathrm{x}^{2}$ & Df & $p$ & GFI & CFI & RMSEA \\
\hline $\begin{array}{l}\text { Model 1: (original) } \\
\text { Three-factor 15-item }\end{array}$ & 309.30 & 87 & .01 & .87 & .82 & .10 \\
$\begin{array}{l}\text { Model 2: (-ftr5 item) } \\
\text { Three-factor 14-item }\end{array}$ & 249.72 & 74 & .01 & .89 & .84 & .10 \\
$\begin{array}{l}\text { Model 3: (-ftr5 \& 2 item) } \\
\text { Three-factor 13-item }\end{array}$ & 198.25 & 62 & .01 & .91 & .87 & .09 \\
\hline
\end{tabular}

\subsection{Internal Consistency}

Internal consistency reliability was assessed using Cronbach's alpha and average inter-item correlation. Cronbach's index of internal consistency ranged from 0.61 to 0.84 (see Table 2), with two subscales showing acceptable alpha coefficient $(\alpha>0.70$; Kline, 2005) and one subscale showing moderately low alpha coefficient $(0.61<\alpha<0.70$; Kline, 2005). However, since alpha coefficient is affected by the number of items (Cortina, 1993), it is supported that when the number of items is small, the measure should be considered as reliable (Schmitt, 1996). In the present study, the one factor that exhibited alpha values below the acceptable limit comprised of four items. According to Ntoumanis (2001) and Pallant (2010) the value 0.61 of factor present in this study can be considered as satisfactory since it is comprised of less than ten items (four items).

\section{Discussion}

This exploratory research examining the factor structure of RSS in a Greek sample supports the 13-item, 3-factor model (truth of texts and teachings, fairness, tolerance, and rational choice, xenosophia/ inter-religious dialog). Other hypothesized models of the RSS measure were not supported by the data.

The findings of the initial check of structure validity of RSS showed low or no correlations among items of the subscale fairness, tolerance, and rational choice. Tabachnick and Fidell (2001) claim that correlations exceeding .30 provide enough evidence to indicate that there is enough commonality to justify comprising factors. The subject of short or limited correlation among items of the subscale ftr sets an issue of content validity, i.e. whether the items of this subscale explain the same construct. Also the problem of items of factor $\mathrm{ftr}$ is made obvious by the important correlations of ftr 2 and ftr 5 item with the items of the factor xenos.

The factorial structure of the three-factor, 15-item of the original RSS was not supported by the findings of EFA in the present study. EFA assists the better examination of the entire factor pattern and structure in order not to eliminate important information relevant to the item analysis of a scale something that may happen by the exclusive use of CFA (Thompson, 1997). The findings of EFA showed a four-factor structure where a crossloading item on two factors appeared. When an item loads on more than one factor, this should be removed if the 
cross-loading is greater than .40 (Schonrock-Adema, Heijne-Penninga, Van Hell, \& Cohen-Schotanus, 2009). The item ftr5 presented loadings of .44 and .57 on two factors and therefore was omitted. On the other hand the findings of the iterative EFA showed a similar factorial structure to the original three-factor 14-item. Once the weak items have been removed, the data should be factored again without the presence of that item for a more refined solution (Pett, Lackey, \& Sullivan, 2003). Nevertheless, this analysis presented alarming findings as well. More specifically this finding presented items with low communalities $(<.40)$. If an item has a communality of less than .40 , it may either a) not be related to the other items, or b) suggest an additional factor that should be explored (Velicer \& Fava, 1998).

Initially, if factor structure of RSS can be replicated in a new study a EFA was used. Since though EFA includes a series of subjective decisions (Byrne, 1989; Jöreskog \& Sörbom, 1989; Pedhazur \& Schmelkin, 1991), it was considered as appropriate to use CFA for the validation of the original model as well as of those examined in EFA. The findings of CFA did not confirm the factorial structure neither of the original model (three-factor, 15-item), nor of the one produced by the EFA (three-factor, 14-item). Nevertheless, following the check of the standardized residual co-variances matrix and with the omission of the ftr2 item as problematic, it was found a marginal satisfactory for the model three-factor, 13-item. Especially the values of fit indicators GFI and RMSEA were found to be marginally satisfactory. These values were found to be of this level probably due to the sensitivity of the indicators of unspecified factor loading, as presented by EFA in the present study (Hu \& Bentler, 1998). On the contrary, the CFI value was below acceptance.

\section{Conclusion}

Finally and based on the findings of the present study, we may consider that factorial structure of the RSS is multidimensional with three-factors and 13-item. This claim is further supported since model fit statistics are simply guidelines and should not be interpreted as golden rules (Marsh, Hau, \& Wen, 2004). It is considered that with the present form of the RSS instrument, it can be used at the Greek population. Another conclusion is the fact that the subscale of fairness, tolerance, and rational choice needs further processing and enhancement by items. In conclusion, the RSS appears to be a valid and reliable instrument.

\section{Limitations}

The present study shows some limitations. A first limitation was the sample used consisting of just Christian Orthodox individuals. A second limitation was the fact that the factorial structure of the RSS was examined at a large range of ages and not on specific age groups. It is suggested to further examine structure validity between age groups in future studies.

\section{References}

Agius, F., Gonzalez-Lamothe, R., Caballero, J. L., Munoz-Blanco, J., Botella, M. A., \& Valpuesta, V. (2003). Engineering increased vitamin C levels in plants by over expression of a Dgalacturonic acid reductase. Nature Biotechnology, 21, 177-181. http://dx.doi.org/10.1038/nbt777 
Asparouhov, T., \& Muthen, B. (2009). Exploratory structural equation modeling. Structural Equation Modeling, 16, 397-438. http://dx.doi.org/10.1080/10705510903008204

Blunch, N. J. (2008). Introduction to structural equation modeling using SPSS and AMOS. Thousand Oaks, CA: Sage.

Brislin, R.W. (1986). The wording and translation of research instruments. In W. J. Lonner \& J. W. Berry (Eds.), Field methods in educational research (pp. 137-164). Newbury Park, CA: Sage.

Brown, T. A. (2006). Confirmatory factor analysis for applied research. New York, NY: Guilford. http://dx.doi.org/10.1080/00036810600603377

Browne, M. W., \& Cudeck, R. (1993). Alternative ways of assessing model fit. In K. A. Bollen \& J. S. Long (Eds.), Testing structural equation models (pp. 132-162). Newbury Park, CA: Sage.

Byrne, B. M. (1989). A primer of LISREL: Basic applications and programming for confirmatory factor analytic models. New York: Springer-Verlag. http://dx.doi.org/10.1007/978-1-4613-8885-2

Byrne, B. M. (2001). Structural equation modeling with AMOS. Basic concepts, applications, and programming. Mahwah, NJ: Erlbaum.

Cortina, J. M. (1993). What is coefficient alpha? An examination of theory and applications. Journal of Applied Psychology, 78, 98-104. http://dx.doi.org/10.1037/0021-9010.78.1.98

Cronbach, L. J, \& Meehl, P. E. (1955). Construct validity in psychology tests. Psychological Bulletin, 52, 281-302. http://dx.doi.org/10.1037/h0040957

Fowler, J. W. (1981). Stages of faith. New York: HarperCollins.

Fowler, J. W. (1986). Faith and the structuring of meaning. In C. Dykstra \& S. D. Parks (Eds.), Faith development and Fowler (pp. 15-42). Birmingham, AL: Religious Education Press.

Gorsuch, R. L. (1983). Factor analysis. Hillsdale, NL: Erlbaum.

Harman, H.H. (1976). Modern factor analysis. Chicago, IL: The University of Chicago Press. Hinkin, T. R. (1995). A review of scale development practices in the study of organizations. Journal of Management, 21, 967-988. http://dx.doi.org/10.1177/014920639502100509

Hu, L., \& Bentler, P. M. (1999). Cutoff criteria for fit indexes in covariances structure analysis: Conventional criteria versus new alternatives. Structural Equation Modeling, 6, 1-55. http://dx.doi.org/10.1080/10705519909540118

Hutchinson, S. R., \& Olmos, A. (1998). Behavior of descriptive fit indices on confirmatory factor analysis using ordered categorical data. Structural Equation Modeling, 5, 344-364. http://dx.doi.org/10.1080/10705519809540111

Jöreskog, K. G., \& Sörbom, D. (1989). LISREL 7: A guide to the program and application. Chicago: SPSS.

Kline, R. B. (2005). Principles and practice of structural equation modeling (2nd ed.). New York: The Guilford Press. 
MacCallum, R. C., Roznowski, M., \& Necowitz, L. B. (1992). Model modifications in covariance structure analysis: The problem of capitalization on chance. Psychological Bulletin, 111, 490-504. http://dx.doi.org/10.1037/0033-2909.111.3.490

Marsh, H. W., Hau, K. T., \& Wen, Z. (2004). In search of golden rules: Comment on hypothesis testing approaches to setting cutoff values for fit indexes and dangers in overgeneralizing $\mathrm{Hu}$ and Bentler's (1999) findings. Structural Equation Modeling, 11, 320-341. http://dx.doi.org/10.1207/s15328007sem1103_2

Marsh, H. W., Liem, G. A. D., Martin, A. J., Morin, A. J. S., \& Nagengast, B. (2011). Methodological measurement fruitfulness of exploratory structural equation modeling (ESEM): New approaches to key substantive issues in motivation and engagement. Journal of Psychoeducational Assessment, 29(4), 322-346. http://dx.doi.org/10.1177/0734282911406657

McIntosh, D. N. (1995). Religion-as-schema, with implications for the relation between religion and coping. The International Journal for the Psychology of Religion, 5(1), 1-16. http://dx.doi.org/10.1207/s15327582ijpr0501_1

Nunnally, J. (1978). Psychometric theory (2nd ed.). New York, NY: McGraw-Hill.

Ntoumanis, N. (2001). A step-by-step guide to SPSS for sport and exercise studies. London and New York: Routledge.

Olsson, U. H., Foss, T., Troye, S. V., \& Howell, T. D. (2000). The performance of ML, GLS and WLS estimation in structural equation modeling under conditions of misspecification and nonnormality. Structural Equation Modeling, 7(4), 557-595. http://dx.doi.org/10.1207/S15328007SEM0704_3

Pallant, J. (2010). SPSS Survival manual: A step by step guide to data analysis using SPSS for Windows (4th ed.). Maidenhead: Open University Press.

Pedhazur, E., \& Schmelkin, L. P. (1991). Measurement, design and analysis: An integrated approach. Hillsdale, NJ: Lawrence Erlbaum.

Pett, M., Lackey, N. \& Sullivan, J. (2003). Making sense of factor analysis. Thousand Oaks: Sage Publications, Inc.

Schafer, J. L., \& Graham, J. W. (2002). Missing data: Our view of the state of the art. Psychological Methods, 7(2), 147-177. http://dx.doi.org/10.1037/1082-989X.7.2.147

Schmitt, N. (1996). Uses and abuses of coefficient alpha. Psychological Assessment, 8, 350-353. http://dx.doi.org/10.1037/1040-3590.8.4.350

Schonrock-Adema, J., Heijne-Penninga, M., Van Hell, E.A., \& Cohen-Schotanus, J. (2009). Necessary steps in factor analysis: enhancing validation studies of educational instruments. Medical Teacher, 31, 226-232. http://dx.doi.org/10.1080/01421590802516756

Stevens, J. (1996). Applied multivariate statistics for the social sciences. Mahwah, NJ: Erlbaum.

Streib, H. (2011). Does religious cognition promote or prevent xenophobia and violence in adolescents? Results from $s$ German sample. Retrieved from http://www.uni-bielefeld.de/theologie/CIRRuS-downloads/CIRRuS-Research-Report4-Xeno phobia-Violence-Religion\%282010-04-08\%29.pdf 
Streib, H., \& Klein, C. (2012). Violence _religion - masculinity: German students' readiness for mediation. Paper presented at the ISREV Meeting 2012. Retrieved from http://pub.uni-bielefeld.de/luur/download?func=downloadFile\&recordOId=1901944\&fileOId $=2516935$

Streib, H., \& Klein, C. (2014). Religious styles predict interreligious prejudice: A study of German adolescents with the religious schema scale. International Journal for the Psychology of Religion, 24(2), 151-163. http://dx.doi.org/10.1080/10508619.2013.808869

Streib, H., Hood, R. W., \& Klein, C. (2010). The religious schema scale: Construction and initial validation of a qualitative measure for religious styles. The International Journal for the Psychology of Religion, 20, 151-172. http://dx.doi.org/10.1080/10508619.2010.481223

Thompson, B. (1997). The importance of structural coefficients in structural equation modeling confirmatory factor analysis. Educational and Psychological Measurement, 57(1), 5-19. http://dx.doi.org/10.1177/0013164497057001001

Velicer, W. F., \& Jackson, D. N. (1990). Component Analysis Versus Common Factor-Analysis - Some Further Observations. Multivariate Behavioral Research, 25(1), 97-114. http://dx.doi.org/10.1207/s15327906mbr2501_1

Watson, P. J., Chen, Z., \& Morris, R. J. (2014). Varieties of Quest and the Religious Openness Hypothesis within Religious Fundamentalist and Biblical Foundationalist Ideological Surrounds. Religions, 5, 1-20. http://dx.doi.org/10.3390/re15010001

\section{Copyright Disclaimer}

Copyright reserved by the author(s).

This article is an open-access article distributed under the terms and conditions of the Creative Commons Attribution license (http://creativecommons.org/licenses/by/3.0/). 